\title{
Performance Evaluation of Straw chopper cum spreader for Paddy crop
}

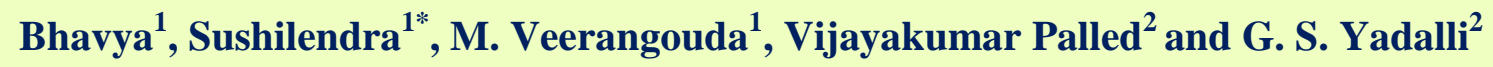 \\ ${ }^{1}$ Department of Farm Machinery and Power Engineering, ${ }^{2}$ Department of Renewable Energy \\ Engineering, College of Agricultural Engineering, University of Agricultural Sciences, \\ Raichur-584104, Karnataka, India \\ *Corresponding author
}

\section{A B S T R A C T}

\begin{tabular}{|l|}
\hline Ke y w o r d s \\
$\begin{array}{l}\text { Straw chopper cum } \\
\text { spreader, field } \\
\text { capacity, fuel } \\
\text { consumption, } \\
\text { chopped straw } \\
\text { length }\end{array}$ \\
\hline Article Info \\
\hline $\begin{array}{l}\text { Accepted: } \\
\text { 30 March 2020 } \\
\text { Available Online: } \\
\text { 10 April 2020 }\end{array}$ \\
\hline
\end{tabular}

Paddy is major crop of India. The grain to straw ratio in paddy crop is $1: 1.25$ and paddy crop generates huge amount of biomass and it alone contributes $34 \%$ to total biomass production in India. Mostly combines are used for harvesting the paddy crop. The end use of paddy straw is not yet wide spread either on farm or in industrial sector. Thus straw management in combine harvested paddy fields is a major problem in paddy fields. To overcome this problem, it was proposed that paddy straw is first chopped and then incorporated in soil with minimum tillage efforts. The straw choppers cum spreaders are widely used for harvesting the paddy stubbles for large and small farmers. Keeping in view the research study was conducted in order to determine the performance of straw chopper cum spreader for harvesting the paddy stubbles in combine harvested fields instead of on farm burning of paddy straw. The machine was operated in the speed ranging from 2.5 to $3 \mathrm{~km} \mathrm{~h}^{-1}$ with cylinder speed of $1600-2000 \mathrm{rpm}$ and their effect on length of straw and fuel consumption was also studied. The results obtained from evaluation of straw chopper cum spreader for harvesting paddy stubbles showed that the size of chopped straw material and fuel consumption were 80 to $120 \mathrm{~mm}$ and 5.5 to $61 \mathrm{~h}^{-1}$ respectively with $0.45 \mathrm{ha} \mathrm{h}^{-1}$ average field capacity of machine.

\section{Introduction}

Paddy is one of the major crop and staple food crop of India among cereals. It is cultivated world wide in an area of 161.1 million ha with production of 719.73 million tonnes. (Anon., 2018 a). India is the second largest producer of paddy in the world after china with production of 112.91 million tonnes in 42.95 million ha area during 20172018. The average productivity of paddy in India is $2585 \mathrm{~kg} \mathrm{ha}$. Karnataka has a production of 2.359 million tonnes from 0.874 million ha area and the productivity is $2699 \mathrm{~kg} \mathrm{ha}^{-1}$.

The grain to straw ratio in paddy varies from $1: 1.2$ to $1: 1.26$ and it generally assumed as 1 : 1 (Thakur et al., 2000). For the current level of paddy production of 112.91 million tonnes , the amount of paddy straw generated is 122.6 Mt. Out of this, around 30.65 million tonnes of paddy straw alone is burnt in India. Paddy straw burning records highest in West 
Bengal (4.30 Mt) followed by Uttar Pradesh (3.57 Mt), Punjab (3.25 Mt) and Andhra Pradesh (3.38 Mt). In Karnataka out of 4.3 Mt of paddy straw generation, $1.07 \mathrm{Mt}$ of straw is burnt annually (Pathak et al., 2010).

Although number of uses of paddy straw are available like as cattle feed, as packaging material for horticultural crops, as bedding for ruminants and in thermal power generation but still all these uses account up to $20 \%$ of paddy straw and rest is considered as waste and is burnt in the fields. So about $60-70 \%$ farmers opt for burning of paddy straw. This practice needs to be discouraged because burning of paddy residue is not only a source of atmospheric pollution but it also leads to loss rich organic matter.

Singh, A. et al. (2010) studied the performance of tractor operated paddy straw chopper cum spreader with 2.5 to $3 \mathrm{~km} \mathrm{~h}^{-1}$ forward speed and cylinder speed of 2000 rpm. They concluded that the chopped straw size was in the range of 70-100 $\mathrm{mm}$, the fuel consumption was 5-5.5 $\mathrm{l} \mathrm{h}^{-1}$ and the field capacity of the machine was 0.4 to 0.6 ha $\mathrm{h}^{-}$ ${ }^{1}$.Garg (2004) conducted a study on tractor operated paddy straw chopper cum spreader. The observed field performance results were chopped straw size of 70 to $100 \mathrm{~mm}$, fuel consumption was 5 to $5.5 \mathrm{l} \mathrm{h}^{-1}$ and field capacity was 0.4 to $0.6 \mathrm{ha} \mathrm{h}^{-1}$ at 2.5 to $3 \mathrm{~km} \mathrm{~h}^{-}$ ${ }^{1}$ speed of operation and $2000 \mathrm{rpm}$ chopper speed. Anonymous (2006) compared a flail type rice straw chopper cum spreader and a cutter bar type straw chopper cum spreader. A reel was attached in front of the cutter bar for proper cutting. The field capacity of both the machines varied from 0.35 to 0.40 ha $h^{-1}$ when operated at a speed of $2.70 \mathrm{~km} \mathrm{~h}^{-1}$. The fuel consumption for cutter bar machine was low (3.60 to $4.10 \mathrm{l} \mathrm{ha}^{-1}$ ) as compared to flail type (4.30 to $5.60 \mathrm{l} \mathrm{h}^{-1}$ ) due to lower energy consumption for cutting by serrated blades. Choking in front of cutting mechanism was observed for cutter bar type machine

\section{Materials and Methods}

\section{Salient features of the machine}

Straw chopper cum spreader is a machine which performs chopping and spreading of straw left by the combine harvester in a single operation. In this machine the harvesting and chopping sections were combined. The harvesting unit consists of cutter bar unit, reel, beater and platform auger through which the crop is cut, collected and conveyed to the chopping unit. Chopping unit consists of two cylinder drums with knives attached on its periphery to chop the straw. The Chopping cylinder consists of a revolving cylinder known as rotary shafts which imparts impact force required to bruise the straw into small pieces. The rotary shaft is mounted on the frame with bearing and is rotated. The chopping cylinders diameter is $145 \mathrm{~mm}$ and it consisted of 17 blades mounted on one row. Similarly 4 rows were mounted on its periphery in staggered manner to create impact and shearing action on straw material for bruising. The serrated blades are in trapezoidal shape and the upper part of the blade consists a slot to grab the material for better bruising action. The straw after cutting by the blades was passed on to the chopping mechanism. The chopped and spreaded stubbles can be buried easily in the soil with minimum tillage efforts by the use of traditional tillage

\section{Experimental procedure for performance evaluation}

To solve the problem of paddy straw management in the field and to study the performance of the chopper cum spreader, the performance evaluation of the machine was conducted in the farmers field at kalmala village of Raichur District. The forward speed was maintained in the range of 2.5 to $3 \mathrm{~km} \mathrm{~h}^{-1}$ with chopping cylinder speed in the range of 
1600 to $2000 \mathrm{rpm}$ and these two factors were selected as independent variables to assess the performance parameters in term of chopped length of straw, fuel consumption and field capacity.

\section{Measurement of chopped length of straw}

From the samples of straw taken one at a time from field, approximately 50 pieces were picked randomly and their lengths were measured with a standard scale. The mean length $(\mathrm{mm})$ and S.D. were determined carefully for each sample. The reduction in awns size was also observed, by observing the length of awns present in the sample.

\section{Fuel consumption}

The tank is filled to full capacity before and after the test.Amount of refuelling after the test is the fuel consumption for test. While filling up the tank, careful attention was paid to keep the tank horizontal and not to leave empty space in tank. The fuel consumption will give an idea of energy requirement by the straw combine for operation (IS 15805-2, 2008).

\section{Field capacity}

For calculating effective field capacity, the time consumed for actual work and lost for other activities such as turning and machine adjustment. Refuelling and machine trouble time was not added in this time.

Effective field capacity was calculated by using following formula

$$
\text { E.F.C }=\frac{A}{T_{P}+T_{L}}
$$

Where,

E.F.C. $=$ Effective field capacity, ha $\mathrm{h}^{-1}$ $\mathrm{A}=$ Total area actually covered by machine, ha

$\mathrm{T}_{\mathrm{P}}=$ Productive time of the machine, $\mathrm{h}$

$\mathrm{T}_{\mathrm{L}}=$ Non productive time, $\mathrm{h}$ or time lost during turning and machine adjustment.

An experiment of randomized block design was used to conduct the experiment and test the significance of variables and their interactions.

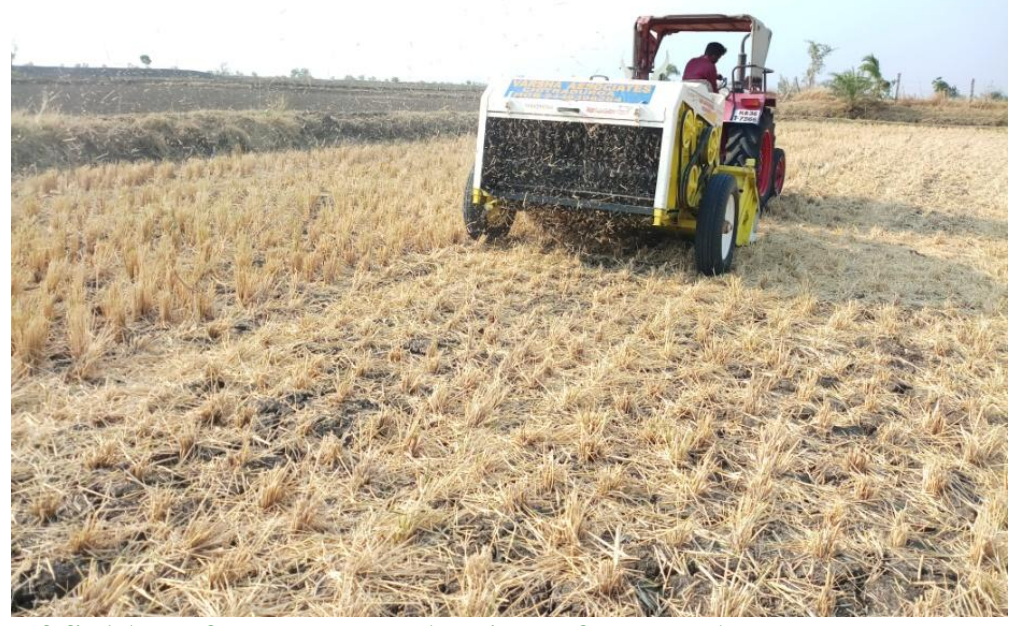

Fig.1 A view of field performance evaluation of straw chopper cum spreader for paddy 


\section{Results and Discussion}

The data collected during machine operation in the field was statistically analysed and results are discussed as follows and the field performance results of straw chopper cum spreader obtained are shown in Table 1.

\section{Chopped length of straw}

The results showed that, the chopped length of straw decreased as the forward speed increased in the range of $2.5 \mathrm{~km} \mathrm{~h}^{-1}$ to $3.5 \mathrm{~km}$ $\mathrm{h}^{-1}$ (Fig. 2). The decrease in chopped length of straw may be due to fact that amount of straw to be cut i.e., feed rate increased by increasing forward speed which leads to less slippage and proper compression. The results also indicated that, chopped length of straw decreased with the increase in cylinder speed in the range of 1600 to $1800 \mathrm{rpm}$.

It is due to increase in number of cuts per unit time and at high speeds, the motion of blade of chopping cylinder relative to material was higher which causes maximum chopping of straw which leads to minimum chopped length of straw. The analysis of variance showed that the concave bar spacing, forward speed and cylinder speed were significant at $5 \%$ level of significance and all interactions were significant at $5 \%$ level of significance. Garg (2004) and Singh, A. et al. (2010)

Table.1 Field performance results of straw chopper cum spreader for paddy crop

\begin{tabular}{|l|c|}
\hline Parameter & Observations \\
\hline Crop & Paddy \\
\hline Height of stubbles before harvest, $\mathbf{m m}$ & $280-340$ \\
\hline No of hills/ $\mathbf{~ m}^{\mathbf{2}}$ & $18-25$ \\
\hline Straw density, $\mathbf{~ k g / \mathbf { m } ^ { 2 }}$ & $0.28-0.32$ \\
\hline Speed of operation, $\mathbf{k m} / \mathbf{h}$ & $2.5-3.5$ \\
\hline Chopping cylinder speed & $1600-2000$ \\
\hline Chopped straw size, $\mathbf{m m}$ & $80-120$ \\
\hline Fuel consumption, $\mathbf{l} / \mathbf{h}$ & $5.5-6$ \\
\hline Field capacity, ha/h & 0.45 \\
\hline Labour requirement, $\mathbf{m a n}-\mathbf{h} / \mathbf{h a}$ & 1.25 \\
\hline
\end{tabular}




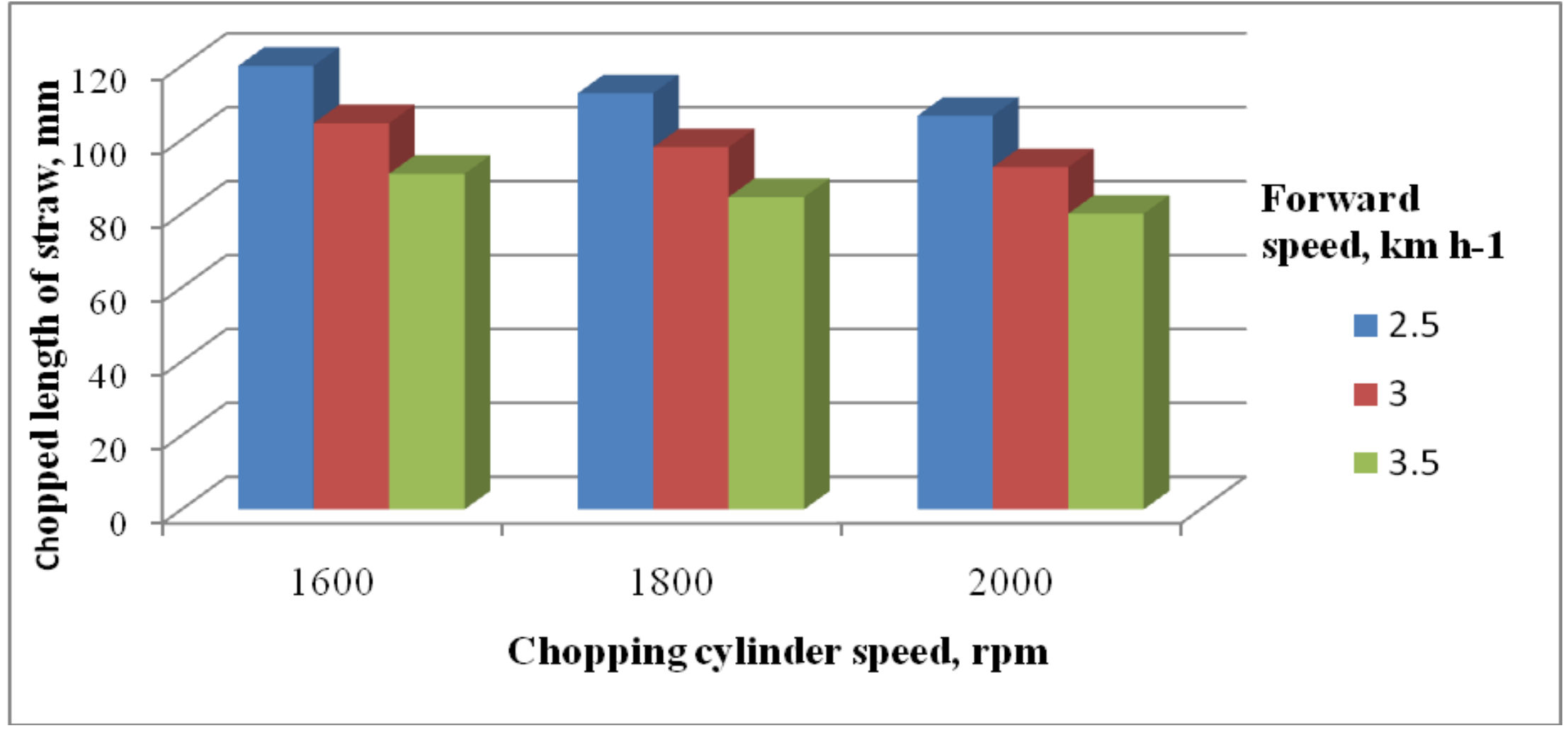

Fig.2 Effect of forward speed and chopping cylinder speed on chopped length of straw 
Int.J.Curr.Microbiol.App.Sci (2020) 9(4): 3209-3215

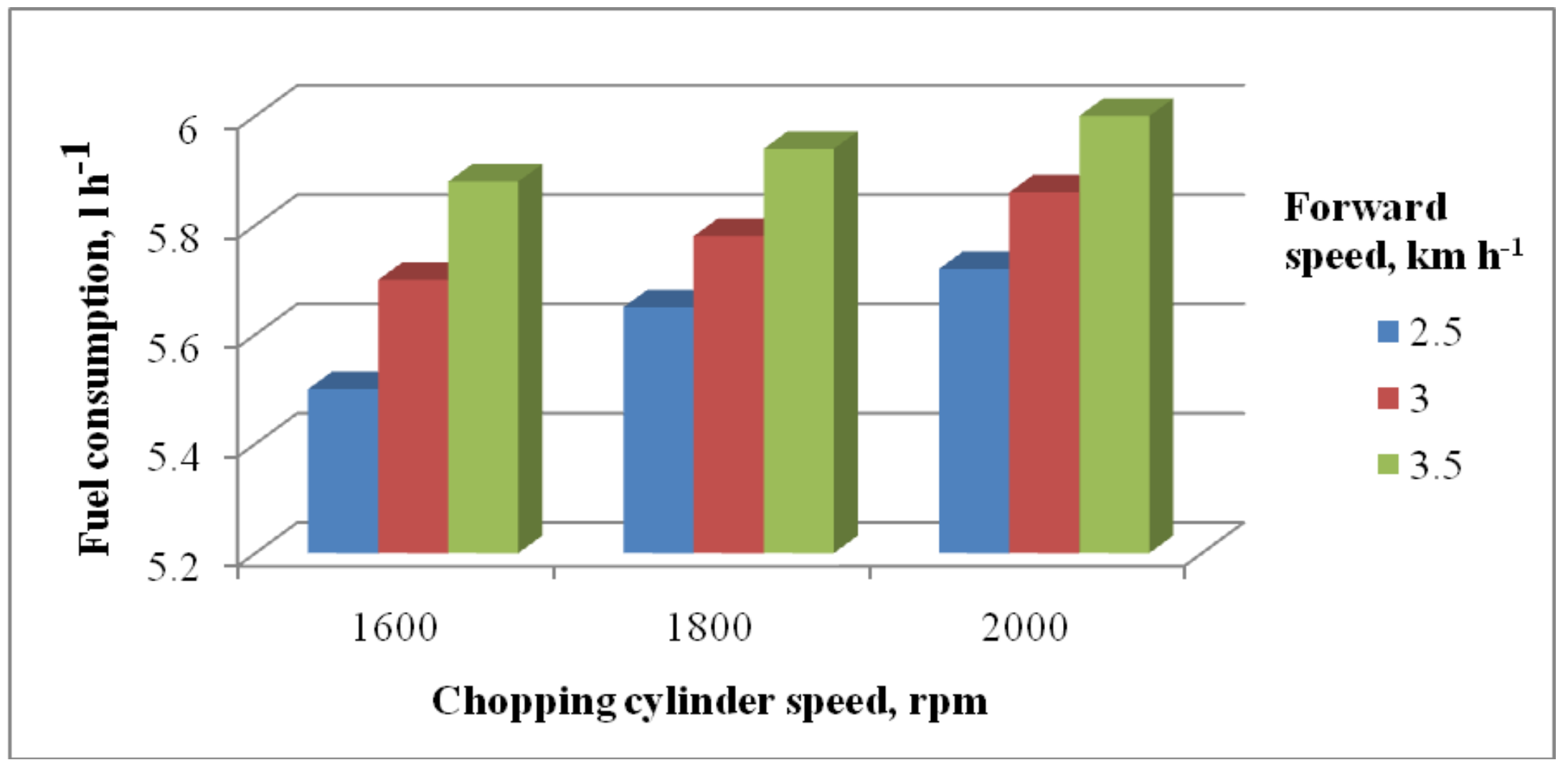

Fig.3 Effect of forward speed and chopping cylinder speed on fuel consumption 
The performance evaluation of straw chopper cum spreader was conducted in paddy field. The size of chopped straw material and fuel consumption were 80 to $120 \mathrm{~mm}$ and 5.5 to 6 $1 \mathrm{~h}^{-1}$ respectively. The size of chopped material decreased with increase in forward speed and cylinder speed. The fuel consumption was found to be increased with increase in forward speed and cylinder speed. The average field capacity of the machine was found to be $0.45 \mathrm{ha} \mathrm{h}^{-1}$ at about $3 \mathrm{~km} \mathrm{~h}^{-1}$ speed of operation. With the use of straw chopper cum spreader, the straw conservation can be improved by insitu management of paddy straw rather than burning it in the paddy fields itself.

\section{References}

Anonymous, 2006, Design, development and testing of flail type chopper cum spreader for rice straw. Technical bullet in AICRP on Farm Implements and Machinery. Punjab Agricultural University, Ludhiana center. Biannual Report.
Anonymous, 2018a, Agricultural statistics at a glance, Ministry of Agriculture, GOI.

Garg, I. K., 2004, Design and development of tractor operated paddy straw chopper cum spreader. J. Res. Punjab Agric. Univ., 41(1): 130-138.

IS 15805-2, 2008, Test code for straw reapercombine. Indian standards institution, Govt. of India, New Delhi. p. 1-9.

Pathak, H., Bhatia, A., Jain, N. and Agarwal, P. K., 2010, Greenhouse gas emission and mitigation in Indian agriculture - A review, In ING Bulletins on Regional Assessment of Reactive Nitrogen. Bulletin No., SCON-ING, New Delhi, pp: 34

Singh, A., Dhaliwal, I. S. and Dixit, A., 2011, Performance evaluation of tractor mounted straw chopper cum spreader for paddy straw management. Indian J. Agric. Res. 45(1): 21-29.

Thakur, T. C., Omar, A. B. and Verma, M. L., 2000, Collection, densification and utilization of paddy and wheat straw. Agric. Engg. Today., 24(4): 1-16.

\section{How to cite this article:}

Bhavya, Sushilendra, M. Veerangouda, Vijayakumar Palled and Yadalli, G. S. 2020. Performance Evaluation of Straw chopper cum spreader for Paddy crop. Int.J.Curr.Microbiol.App.Sci. 9(04): 3209-3215. doi: https://doi.org/10.20546/ijcmas.2020.904.373 